\title{
Pre-operative Embolization as Resection Strategy in Brain Tumor with No Neurological Deficit
}

\author{
Andi N. Sendjaja, Yogi Rosbianto, Agung B. Sutiono, Bilzardy F. Zulkifli, \\ Roland Sidabutar, Achmad Adam, Muhammad Z. Arifin \\ Department of Neurosurgery \\ Faculty of Medicine Padjadjaran University-Dr. Hasan Sadikin General Hospital \\ Jl. Pasteur No.38 Bandung, Indonesia \\ Email: andsendjaja@gmail.com
}

\begin{abstract}
Meningioma is an intracranial tumor that generally involves meninges. This tumor can be found along the dura layers at the skull base. Meningioma has vast vascularization from the arteries near dura attachment. Pre-operative embolization technique is an effective strategy to prevent intra-operative complications and better outcomes. The patient was a 24 year-old woman who has been complaining of headaches since 2 months ago. The CT Scan resulted in a $12 \times 9 \times 7 \mathrm{~cm}$ isodense mass in the left temporoparietal enhanced homogenously by contrast. Pre-operative embolization was performed on the tumor feeding artery as a strategy to prevent intra-operative blood loss. A left frontotemporosphenoidal craniotomy was performed 10 days after embolization to remove the tumor. A complete resection was successfully achieved with less intraoperative blood loss and without complication. The pathology examination resulted in meningotheliomatous meningioma. A follow-up picture showed no recurrent tumor after resection and the patient had no symptoms and neurological deficits until 6 months after the surgery. In conclusion, meningioma is a common intracranial tumor with a lot of blood supply. However, tumor resection can be safely and efficaciously performed with good pre-operative strategy.
\end{abstract}

Keywords: brain tumor, embolization, meningioma, resection, skullbase 


\title{
Embolisasi Preoperatif sebagai Strategi Reseksi pada Tumor Otak Tanpa Tanda Defisit Neurologis
}

\author{
Andi N. Sendjaja, Yogi Rosbianto, Agung B. Sutiono, Bilzardy F. Zulkifli, \\ Roland Sidabutar, Achmad Adam, Muhammad Z. Arifin \\ Departemen Bedah Saraf \\ Fakultas Kedokteran Universitas Padjadjaran/RSUP Dr. Hasan Sadikin Bandung \\ Jl. Pasteur 38, Bandung 40161, Indonesia \\ Email: andsendjaja@gmail.com
}

\begin{abstract}
Abstrak
Meningioma adalah tumor intrakranial yang pada umumnya melibatkan meningen. Lokasi tumor ini dapat ditemukan di sepanjang duramater pada dasar tengkorak. Meningioma memiliki vaskularisasi yang kaya arteri di dekat penempelan dura. Teknik embolisasi preoperative merupakan strategi yang efektif untuk mencegah komplikasi intraoperatif dengan luaran yang lebih baik. Pasien adalah seorang wanita 24 tahun dengan keluhan nyeri kepala dan penglihatan buram pada mata kiri sejak 2 bulan yang lalu. $C T$ scan menunjukkan adanya lesi massa isodens berukuran $12 \times 9 \times 7 \mathrm{~cm}$ pada temporoparietal kiri yang meningkat secara homogen dengan pemberian kontras. Embolisasi preoperatif dilakukan pada arteri penyuplai tumor sebagai strategi untuk mencegah perdarahan intraoperatif. Kraniotomifrontotemporospenoidal dilakukan untuk mengangkat tumor dilakukan setelah embolisasi. Reseksi lengkap berhasil dilakukan dengan sedikit perdarahan intraoperatif dan tanpa komplikasi. Pemeriksaan patologi menunjukkan meningotheliomatous meningioma. CT Scan lanjutan menunjukkan tidak adanya rekurensi tumor, selain itu tidak ada keluhan dan deficit neurologisd alam 6 bulan setelah pembedahan. Simpulan, meningioma merupakan tumor intrakranial yang sering ditemukan dengan suplai darah yang kaya, namun reseksi tumor akan aman dan efektif dengan strategi preoperatif yang baik.
\end{abstract}

Kata kunci: dasar tengkorak, embolisasi, meningioma, reseksi 
Case Report

\section{Introduction}

Meningioma is a common intracranial tumor, approximately $15-20 \%$ of all intracranial tumors. ${ }^{1,2}$ It can be found along the dura lining of the venous sinuses of the brain and skull base, commonly found at the cerebral convexity, petrous ridge, sphenoid wing, tentorium, foramen magnum, cerebellopontine angle, and cavernous sinus. ${ }^{3,4}$ Meningioma has many vascularization from surrounding arteries. ${ }^{5}$ Surgical morbidity are shown to be $30 \%$ and mortality $4 \%$ in general population. The most common surgical risk is intra-operative blood loss due to high vascularization. ${ }^{2}$ Pre-operative embolization has been advocated to reduce intra-operative blood loss and facilitate surgical resection. ${ }^{3,6}$ This is an effective strategy to prevent intra-operative complications and facilitate better outcomes. ${ }^{1}$

\section{Case Report}

The patient was a 24 years old woman experiencing headaches since 2 months ago. She had no neurological deficit on neurological examination. A CT Scan shows a 12 × 9 x $7 \mathrm{~cm}$ isodense mass in left temporoparietal that enhanced homogenously by contrast, with peritumoral edema and a midline shift $>5 \mathrm{~mm}$ to the right (Figure 1). The differential diagnosis at that point was meningioma and glioma.
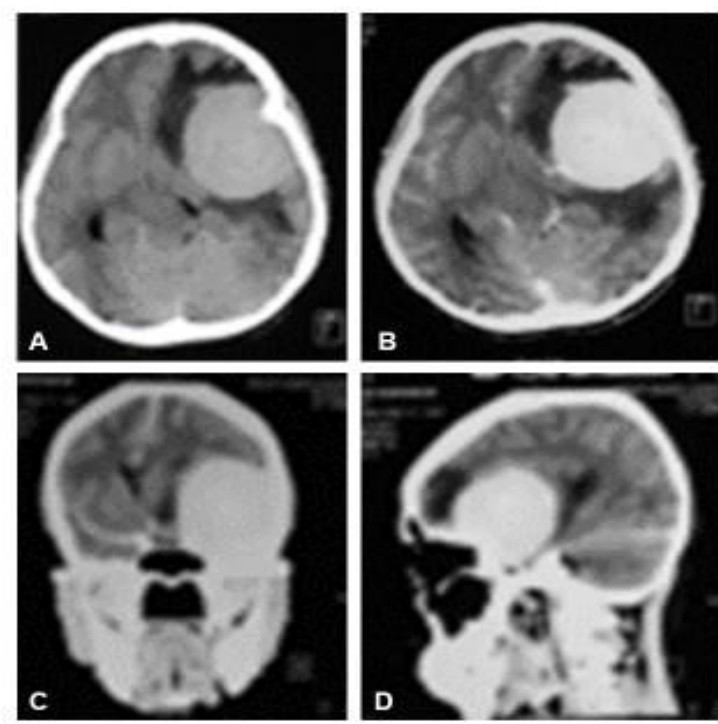

Figure 1 Cranial CT Scan Images of the Patient

(A) Axial Non-contrast Enhanced show isodense mass at left temporoparietal, size $12 \times 9 \times 7 \mathrm{~cm}$, surrounded by peritumoral edema, and midline shift $>5 \mathrm{~mm}$ to the right side.

(B) The mass enhanced homogenously by contrast.

(C) coronal view and

(D) Sagital view after contrast administration. 
Case Report

\section{Procedure}

Pre-operative embolization was performed on the tumor's feeder artery as a strategy to prevent intra-operative blood loss 10 days before tumor resection. All imaging examinations were performed by high resolutions biplane Digital Substraction Angiography (DSA). Using a $5 \mathrm{~F}$ micropuncture set, we punctured and cannulated the right femoral artery and placed a $5 \mathrm{~F}$ arterial sheath over a guide wire. The sheath attached to a continuous heparinized saline flush. Intravenous heparin intermittently administered throughout the procedure, monitored with serial activated clotting time measurements. Selective catheterization of cerebral arteries, including internal carotids, external carotids, and posterior circulation was performed. The tumors blood supply was identified from the branch of middle meningeal artery (Figure2). After we selected appropriate vessels for embolization (left middle meningeal artery), a microcatheterwas inserted to the target vessel and embolization was performed by embolic agent (Onyx 18 Liquid Embolic System; EV3).
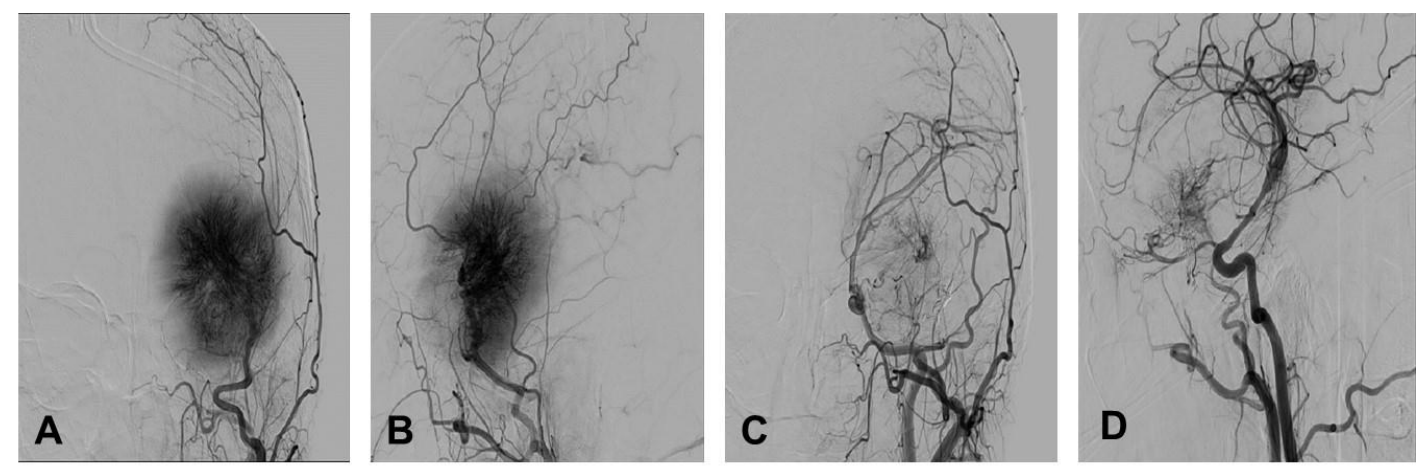

Figure 2 Digital Substraction Angiography Imaging of the Patient

(A) Anteroposterior and (B) lateral view of Left External and Carotid Artery (ECA) shows tumor vascularization from Left Middle Meningeal Artery (MMA).

(C) Anteroposterior and (D) lateral view after embolization using embolic agent at distal site of left MMA show the reduction of tumor vascularization.

Ten days after embolization, a left frontotemporosphenoidal craniotomy was performed to approach tumor in sphenoidal area. The patient placed in the supine position with her head rotated to the right and supported with Sugita Head Frame. A standard preauricular temporal incision was made. ${ }^{7}$ The scalp was elevated with entire temporal muscle and periosteum in a single layer. A standard sub-temporal craniotomy was performed (Figure.3). The anterior subtemporal bones and the sphenoid ridge wasremoved by using bone rongeur. We found infiltration lesion when skeletonizing the temporal base. The tumor was identified intradurally at the temporal area. Durotomy was performed in C-shape and tumor was dissected from arachnoid and dura attachment. Tumor was a gray mass with clear border, indicating a 
Case Report

meningioma. The bleeding tendencywas minimal and complete resection successfully achieved with less intraoperative blood loss $(<200 \mathrm{ml})$.
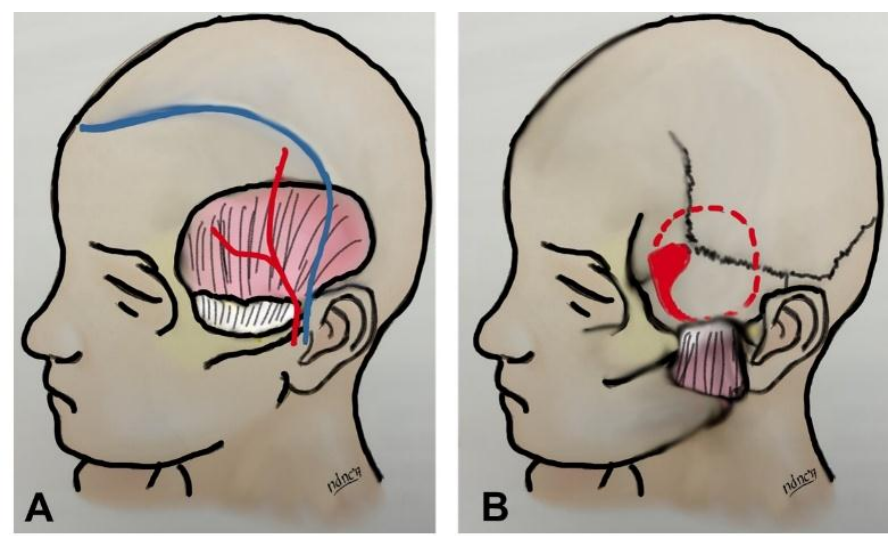

Figure 3(A) Illustration of Incision Line of Skin (preauricular standard incision, blue line) at Temporal Area behind the Superior Temporal Artery (red line). (B). Craniotomy Area at Temporal Bone after Temporal Muscle Retracted to Inferior.
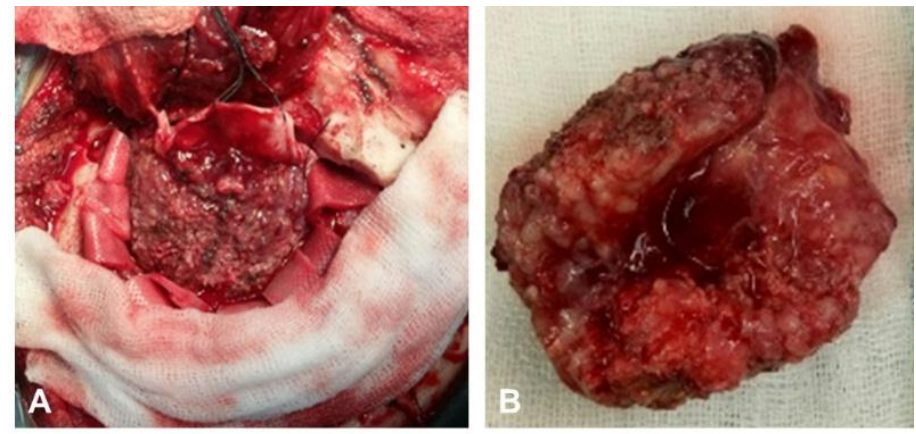

Figure 4 (A) Intraoperative Finding after Craniotomy and Durotomy Shows a Gray Mass with Clear Border at Temporal Duramater. (B) Tumor Mass after Evacuated,

Macroscopic Appearance Indicating a Meningioma.

\section{Pathology Examination and Patient Outcome}

The pathology results shows meningoteliomatous meningioma (WHO grade I) with poorly defined cytoplasmic border and psammoma bodies. This is a common type and benign meningioma. 
Case Report

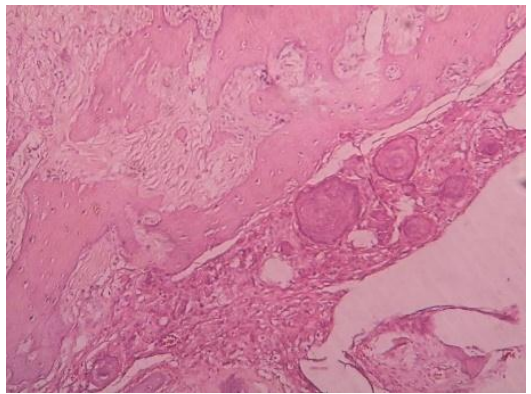

Figure 5 Microphotograph Showing Meningotheliomatous Cells with Psammoma Bodies (on right side) Infiltrating the Adjacent Bony Trabeculae and Fibrous Tissue (on left)

(H\&E X100)

The patient discharged from hospital 5 days after surgery with no neurological deficits and complications. Post-operative CT Scans shows the tumor was totally removed. One month afterthe patient back to work and activities as usual.
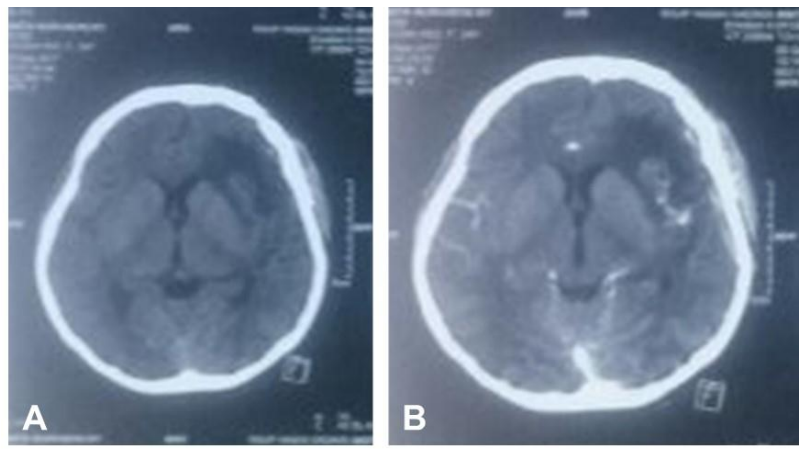

Figure 6 Cranial CT Scan Examination After Surgery. Axial (A) Non-contrast and (B) Contrast Enhanced CT Scans Shows the Tumor Totally Removed

\section{Discussion}

Meningioma is a common intracranial tumor, a slow growing tumor that originate from the arachnoid cap cell of the meninges. It accounted approximately $15-20 \%$ of all intracranial tumors. Majority of intracranial meningioma are benign (90\%) with other forms occur less frequently. ${ }^{2}$ Meningioma is typically diagnosed in adults aged $>60$ years and incidence rate increases with age. This tumor occurs more often in women than in men, the ratio about 2:1. Genetic factors, ionizing radiation exposure, and hormones are the most identified risk factors in meningioma. ${ }^{8}$

Meningioma can be found along the dura lining of the venous sinuses of the brain and skull base, commonly found at the cerebral convexity, petrous ridge, sphenoid wing, tentorium, foramen magnum, cerebellopontine angle, and cavernous sinus. ${ }^{3}$ Depend on the location of 
Case Report

tumor, patients can present with many variety of neurological symptoms, including headaches, visual disturbance, speech problems, cognitive deficits, and motor deficits which related to the compression of adjacent structures. ${ }^{9}$

Meningioma may has vascularization from the external carotid artery (ECA), internal carotid artery (ICA), vertebral artery (VA), or any combination of these vessels. The central region of a meningioma is supplied by dura feeders at the site of dura attachment, while the capsule fed by pial or cortical feeders. ${ }^{5}$

Contrast-enhanced magnetic resonance imaging (MRI) scans with the addition of arterial and venous sequences are the most important studies to evaluate this tumor. Magnetic Resonance (MR) angiography and venography are noninvasive options to demonstrate tumor blood supply, vascularization, drainage veins, and sinus compromise.

Computed Tomography (CT) Scans also can be used to identify meningioma. On Non Enhanced Computed Tomography (NECT), meningioma usually appears as well-circumscribed extra-axial hyperdense to isodense lesions and with contrast agent (CECT), they usually enhance brightly. CT imaging may provide information about bone anatomy. ${ }^{2,9}$

In this case, the patient was 24 year-old female with complaining headache about 2 months ago with no neurological deficits. Meningiomais common in female, but not in young age. There is no history of ionizing radiation exposurenor hormonal exposure and she has not been married nor has children, but family history is unknown. Genetic factor maybe the most suspected cause in this case, but we did not found clear evidence of this. CT Scans is the simplest imaging method to identify intracranial problem in our facility. Patient was referredto our neurology department with CT scan imaging that shows a large extra axial isodense lesion $(12 \times 9 \times 7 \mathrm{~cm})$ at left temporoparietal which was enhanced homogenously with contrast administration.At the CT Bone image, there is no bone hyperostosis or bone destructions. At this point, we decided not to perform MRI because the CTimaging is enough to identify the lesions.

Tumor resection is the best treatment of this case based on size, location, cranial nerve involvement, and relations to brainstem. Although meningioma resectionis considered low-risk, it is still not an easy procedure. ${ }^{1}$ Surgical morbidity shown to be $30 \%$ and mortality $4 \%$ in general population. The most common surgical risk is intra-operative blood loss. ${ }^{2}$

Pre-operative embolization is a well-established adjuvant technique in the management of intracranial meningioma. The advantages of embolization include de-vascularization of thetumor with subsequent decreased operative blood loss, increased ease of tumor visualization, improved safety especially when resecting tumors in eloquent areas and potentially improved 
Case Report

ability to resection. Although this strategy has been performed over 30 years but it still an effective strategy to prevent intraoperative complications and facilitate better outcomes. ${ }^{1,3,5,10}$

This case has an important challenge because the patient was a young productive female with no neurological deficits, so the complication after surgery should be avoided for the survival of patients in her daily life. The good strategy and good experience is the best way to solve this problem. Embolization was performed 10 days before tumor resection. Angiography is an invasive study that is useful to demonstrate the meningioma primary blood supply, which usually derived from dura arteries as branches of the external carotid artery. The degree of vascularization and major draining veins are also visible. Angiography also allows the possibility to perform preoperative selective embolization, usually several days before surgery. ${ }^{9,11}$ We identified, the main blood supply of this tumor was from left external carotid artery and drainaged to Labbe vein. We performed embolization at the main supply artery and the de-vascularization has been successfully. The DSA shows that the tumor vascularization decreased due to embolic agent occlusion. Tumor resection was successfully achieve with less intraoperative blood lossand without intraoperative complications. The tumor was less vascularized and smaller than the imaging result, this was allegedly due to the success of embolization.

The pathology examination showed meningoteliomatous meningioma, which was a benign type. A follow up picture showed no recurrence of the tumor after resection and the patient has no symptoms and neurological deficits 6 months after surgery.

\section{Conclusion}

Meningioma is a common intracranial tumor that can be found along the dura lining of the venous sinuses of the brain and skull base. This tumor may have a lot of blood supply. Tumor resection is the best treatment in most cases but the intraoperative blood loss is the most common surgical risk. Pre-operative embolization is a most effective strategy to prevent intraoperative complications. Tumor resection can be safely and efficaciously performed with good preoperative strategy.

\section{References}

1. James RF, Kramer DR, Page PS, Gaughen JR, Martin LB, WJ M. Strategic and technical considerations for the endovascular embolization of intracranial meningioma. Neurosurg Clin N Am. 2015;11(005):1-12.

2. Almefty R, Haddad GF, Al-Mefty O. Meningiomas. In: HR W, editor. Youmans \& Winn Neurological Surgery. 2. Seventh Edition ed. Philadelphia, PA: Elsevier; 2017. p.4691-754.

3. Dowd CF, Halbach VV, Higashida RT. Meningiomas: the role of the preoperative angiography and embolization. Neurosurg Focus. 2003;15(1):1-4. 


\section{Case Report}

4. Simon M, Schramm J. Lateral and middle sphenoid wing meningiomas. In: De Monte F, McDermott MW, O AM, editors. Al-Mefty's meningiomas. Second edition ed. New York: Thieme; 2011. p. 214-27.

5. Dubel GJ, Ahn SH, Soares GM. Contemporary endovascular embolotherapy for meningioma. Seminars In Interventional Radiology. 2013;30(3):263-78.

6. Shah AH, Patel N, Raper DMS, Bregy A, Ashour R, Elhammady MS. The role of preoperative embolization for intracranial meningiomas. J Neurosurg. 2013;119:1-9.

7. Fischer BR, Brokinkel B. Surgical management of skullbase meningiomas - a overview. In: D M, editor. Meningiomas - management and surgery. Rijeka, Croatia: Intech; 2012. p. 85-102.

8. Clauss EB, AL M. Epidemiology of meningioma. In: De Monte F, McDermott MW, Al-Mefty O, editors. Almefty's meningioma. New York: Thieme; 2011. p. 35-9.

9. Black P, Landriel F. Meningiomas. In: Ellenbogen RG, Abdulrauf SI, Sekhar LN, editors. The principles of neurological surgery. Third edition ed. Philadelphia, PA: Elsevier Saunders; 2012. p. 541-64.

10. Trivelatto F, Nakiri GS, Manisor M, Riva R, Al-Khawaldeh M, Kessler I, et al. Preoperative onyx embolization of meningioma fed by opthalmic artery: a case series. Am J Neuroradiol. 2011;32:1762-7.

11. Raper DMS, Starke RM, Henderson JF, Ding D, Simon S, Evans AJ, et al. Preoperative embolization of intracranial meningiomas: efficacy, technical considerations, and complications. Am J Neuroradiol. 2014;A3919:1-7. 